\title{
Amniotic Fluid Embolism. Is a New Pregnancy Possible? Case Report
}

\section{Embolia do líquido amniótico. Será uma nova gestação possível? Relato de caso}

\author{
Ana Filipa Cabrita Caeiro ${ }^{1}$ Irina Dulce Tapadinhas Matos Ramilo ${ }^{1}$ Ana Paula Santos ${ }^{1}$ \\ Elizabeth Ferreira ${ }^{1}$ Isabel Santos Batalha ${ }^{1}$ \\ ${ }^{1}$ Department of Gynecology and Obstetrics, Hospital Prof. Doutor \\ Fernando Fonseca, Amadora, Portugal \\ Rev Bras Ginecol Obstet 2017;39:369-372.

\begin{abstract}
Address for correspondence Ana Filipa Cabrita Caeiro, M6, Medical student 6th year, Department of Gynecology and Obstetrics, Hospital Prof. Doutor Fernando Fonseca IC19, 2720-276 Amadora, Portugal (e-mail: afilipa.caeiro@gmail.com).
\end{abstract}

\begin{abstract}
Amniotic fluid embolism (AFE) is a rare but potentially catastrophic clinical condition, characterized by a combination of signs and symptoms that reflect respiratory distress, cardiovascular collapse and disseminated intravascular coagulation (DIC). Its pathogenesis is still unclear. More recently, the traditional view of obstruction of pulmonary capillary vessels by amniotic fluid emboli as the main explanation for the etiology has

Keywords

- amniotic fluid embolism

- cardiovascular collapse

- intravascular disseminated coagulation

- maternal death

\section{Resumo}

Palavras-chave

- embolia do líquido amniótico

- colapso cardiovascular

- coagulação intravascular disseminada

- morte materna been ruled out, and immunologic factors and the activation of the inflammatory cascade took on an important role. Amniotic fluid embolism has an unpredictable character, its diagnosis is exclusively clinical, and the treatment consists mainly of cardiovascular support and administration of blood products to correct the DIC. No diagnostic test is recommended until now, though multiple blood markers are currently being studied. The authors present a case report of a woman who had survived AFE in her previous pregnancy and had a subsequent pregnancy without recurrence, providing one more clinical testimony of the low risks for the pregnancy after AFE.

A embolia do liquido amniótico (ELA) é uma situação clínica rara, mas potencialmente catastrófica, que se caracteriza por uma combinação de sinais e sintomas clínicos que refletem insuficiência respiratória aguda, colapso cardiovascular e coagulação intravascular disseminada (CID). A sua patogênese ainda não é totalmente compreendida. Mais recentemente, a visão tradicional de obstrução dos capilares pulmonares por êmbolo de líquido amniótico, como explicação principal para a etiologia desta síndrome, tem sido desconsiderada, assumindo os fatores imunológicos e a ativação das cascatas de resposta inflamatória um papel importante. A embolia do líquido amniótico tem um carácter imprevisível, e o seu diagnóstico é exclusivamente clínico, sendo o tratamento sobretudo de suporte respiratório e cardiovascular, com a concomitante administração de derivados do sangue para corrigir a CID. Nenhum teste de diagnóstico é recomendado até o momento, embora vários marcadores do
\end{abstract}

received

October 7, 2016

accepted

January 9, 2017

published online

May 2, 2017
DOI https://doi.org/

10.1055/s-0037-1601428. ISSN 0100-7203.
Copyright $\odot 2017$ by Thieme Revinter

Publicações Ltda, Rio de Janeiro, Brazil
License terms

(요 (1) $\Theta \circledast$ 
sangue periférico se encontrem em estudo. Os autores apresentam um caso clínico de uma mulher que sobreviveu a um quadro de embolia de líquido amniótico na sua gravidez prévia, e que teve uma gravidez subsequente sem recorrência do quadro, contribuindo com mais um testemunho clínico do baixo risco na gravidez pós-ELA.

\section{Introduction}

Amniotic fluid embolism (AFE) is a rare obstetric condition, first described in 1926 by Meyer $^{1}$, but only recognized in 1941 , when Steiner and Lushbaugh ${ }^{2}$ reported a series of 8 cases of autopsy with fetal mucin and squamous cells in the pulmonary vasculature of women who had died in a sudden chock during labor. Its incidence is difficult to determine, with data ranging from 1 in 12,953 deliveries in the United States to 1 in 56,500 in the United Kingdom. ${ }^{3-9}$ This syndrome has not been clearly understood to this day, with its pathogenesis being constantly updated, and with different roles being played by the amniotic embolus, ${ }^{2,6}$ the immune factors ${ }^{10-12}$ and the inflammatory maternal response to the strange fetal material that enters her vascular circulation.

It is a catastrophic condition, being responsible for 5-15\% of maternal deaths in developed countries, ${ }^{4}$ leading the first three causes in those countries. Even though, it seems that the fatality rate has decreased in the last decades from $86 \%$ to $13-44 \%$, and this is probably associated with better recognition and improvements in the treatment. ${ }^{4,7,8,13}$ However, despite the increment in survival, $\sim 61 \%$ of patients will have some kind of neurological compromise, ${ }^{5}$ with neurological impairment in $50 \%$ of the neonates.

This syndrome is characterized by acute respiratory distress accompanied by cardiovascular collapse and disseminated intravascular coagulation (DIC) that occurs during pregnancy, mainly during labor and delivery, until 48 hours postpartum. Its diagnosis is exclusively clinical, as no marker has yet been recommended, despite the recent efforts to look for serum markers in the maternal circulation, such as zinc coproporphyrin, sialyl Tn antigen, serum tryptase and C3 and C4 complements. $^{10-12}$ The histologic value of the presence of squamous cells in the central venous blood or pulmonary arterial blood has lost its importance as a pathognomonic, as several studies showed their presence in non-AFE cases and only in up to $75 \%$ of AFE cases. ${ }^{3,4,14}$ Moreover, its diagnosis requires exclusion of other situations that may present with some of the same signs and symptoms, such as: anesthetic complications; medication allergy; pulmonary thromboembolism; myocardial infarction; eclampsia; and placental abruption, among others. ${ }^{4,14-18}$ More recently, trying to be more accurate in this diagnosis and for research purposes, international criteria for the diagnosis of AFE have been published. ${ }^{19}$

The treatment relies in early recognition and prompt and aggressive resuscitative efforts, maintaining vital functions and transfusing blood products. Some authors even advocate for the creation of algorithms to manage DIC in these patients, as the treatment requires a huge amount of blood products, considering the transfusion of fibrinogen in the early phases and of recombinant factor VIIa as a rescue therapy. ${ }^{17,18,20}$
In the literature, there are multiple cases and few series that describe the clinical aspects and the support treatments for this syndrome. ${ }^{9,16,17,20-26}$ However, information about longterm maternal and child results is scarce. There are few published cases of successful pregnancies after AFE survival in previous gestations, ${ }^{14,27-32}$ and this case provides another testimony that pregnancy after AFE can have a good outcome.

\section{Case Report}

A 36-year old black woman, born in Guinea-Bissau, in her 6th gestation (para 3), with a pregnancy followed as low-risk in a primary care health facility, and no relevant surgical or medical history, was admitted at her 37th week of gestation in our hospital in active labor ( $3 \mathrm{~cm}$ of cervical dilatation).

Oxytocin was administered during labor, which developed quickly, with the dilatation going from $3 \mathrm{~cm}$ to $9 \mathrm{~cm}$ in 2 hours. At that time, a sudden fetal bradycardia was detected, and prompt extraction of the soon-to-be neonate was performed with the aid of an extractor-vacuum. The newborn was male, weighed 3,195 g, had an Apgar Index of 4/7/8, and was transferred to the neonatal intensive care unit (NICU).

Simultaneously to the extraction of the newborn, the mother coughed, had a seizure, and, finally, a cardiac arrest. Immediate basic cardiorespiratory reanimation was performed, and an anesthesiologist was called. Recovery was quick, and it was achieved using only venous fluids and ephedrine, and the third stage of the labor was concluded. Half an hour later, after an evaluation of the patient by a neurologist, a post-partum hemorrhage was diagnosed, and it was treated with $800 \mu \mathrm{g}$ of rectal misoprostol. Later on, with the revaluation of the labor canal (which showed no active wounds), an abdominal ultrasound was performed, and it showed no evidence of placental debris in uterine cavity. Apart from that a uterine curettage by ultrasound control was performed, and it revealed no exit of placental debris. During this period, the uterus maintained a normal tonus, below the umbilical scar. An unsuccessful insufflation with a SengstakenBlackmore balloon was attempted, because of the adequate uterine tonicity. With these procedures, we were able to rule out the main causes of post-partum hemorrhage (atonic uterus, placental debris in the uterine cavity or lacerations of the labor canal), leaving coagulopathy as the remaining hypothesis for the cause. At the same time, the laboratory results showed a sudden alteration with prolonged coagulation times (INR -2.9; aPTT > 160 seconds), absence of fibrinogen (incoagulable sample), thrombocytopenia $(32,000$ platelets) and anemia (7.0 g/dL hemoglobin). The clinical situation aggravated, with bleeding from venous punctures, hematuria, and abundant incoagulable vaginal bleeding, with consequent 
hypovolemic shock, which was only reverted after intensive reperfusion with fluids and blood products (10 erythrocyte concentrate units, 9 fresh frozen plasma units, 14 cryoprecipitate units, 2 pools of platelet concentrate and 2 recombinant fibrinogen units). The woman was transferred to the intensive care unit (ICU) with hemodynamic stability and had a full recovery, being discharged from the hospital with her newborn on the 5th day after birth.

Two years later, the woman got pregnant again, and because of her labor history, she was examined at our high-risk pregnancy service, and had a normal pregnancy. She went into labor at term spontaneously, and had an eutocic delivery at 39 weeks of gestation. The newborn weighed 3,100 grams, and had a 9/10 Apgar Index. There were no postpartum complications, and the patient was discharged two days later.

\section{Discussion}

The described case report demonstrates how dangerous AFE can be with the imminent risk of death. A multidisciplinary team was the key for the adequate management, because it allowed for an immediate response to multiple clinical issues. In this case, the pregnant woman was multiparous, and the symptoms presented during labor, with a need to intervene for suspected fetal distress represented by a bradycardia, which was recorded in the cardiotocography. The patient suffered a cardiorespiratory arrest with the subsequent development of DIC, which progressed to a serious stage, and a massive transfusion of blood products was needed. The criteria presented in our case meet the new criteria that have been proposed by Clark et al regarding AFE (the symptoms appeared during pregnancy, intensive medical intervention was necessary to treat the cardiac arrest and DIC, there was no other disease that could explain it, and there was no fever), and also meet their criteria for DIC during pregnancy (the platelet count was lower than 50,000, there was an increase of $\sim 50 \%$ in the coagulation time, and the fibrinogen levels were untraceable). ${ }^{19}$

The first report of a successful pregnancy after AFE was published in 1992, with Clark, ${ }^{27}$ describing 2 cases, and proposing a more probable model, with AFE involving chemically abnormal amniotic fluid rather than an unusual sensitivity to normal amniotic fluid. Later, in 1998, Duffy ${ }^{28}$ reported two other cases, and Collier ${ }^{29}$ reported one, pointing out that before 1970 there was a very low probability of survival for this syndrome, so the hypothesis of another pregnancy after it was practically impossible. In 2002, Stiller et $\mathrm{al}^{30}$ described two more cases, followed by another case described by Demianczuk and Corbett ${ }^{31}$ in 2005. Finally, Abecassis and Benhamou ${ }^{32}$, in 2006, described another case, and concluded that here was at least a suggestion that there was little chance of recurrence in a subsequent pregnancy, and that it was possible for patients who had survived AFE to become pregnant again and deliver successfully.

These data are still very insufficient, and we believe that this case provides another testimony of a good outcome, and it may help on the counselling of these women. However, clinical information is still scarce in order for us to draw conclusions, and women's counselling on the risk of recurrence must take into account the severity of this condition and the few reports known.

\section{References}

1 Meyer JR. Embolia-pulmonar amnio-caseosa. Bras Med 1926; 40(02):301-303

2 Steiner PE, Lushbaugh CC. Landmark article, Oct. 1941: Maternal pulmonary embolism by amniotic fluid as a cause of obstetric shock and unexpected deaths in obstetrics. By Paul E. Steiner and C. C. Lushbaugh. JAMA 1986;255(16):2187-2203

3 Clark SL, Pavlova Z, Greenspoon J, Horenstein J, Phelan JP. Squamous cells in the maternal pulmonary circulation. Am J Obstet Gynecol 1986;154(01):104-106

4 Conde-Agudelo A, Romero R. Amniotic fluid embolism: an evidence-based review. Am J Obstet Gynecol 2009;201(05):445. e1-445.e13

5 Tuffnell DJ. United kingdom amniotic fluid embolism register. BJOG 2005;112(12):1625-1629

6 Abenhaim HA, Azoulay L, Kramer MS, Leduc L. Incidence and risk factors of amniotic fluid embolisms: a population-based study on 3 million births in the United States. Am J Obstet Gynecol 2008; 199(01):49.e1-49.e8

7 Kramer MS, Rouleau J, Liu S, Bartholomew S, Joseph KS; Maternal Health Study Group of the Canadian Perinatal Surveillance System. Amniotic fluid embolism: incidence, risk factors, and impact on perinatal outcome. BJOG 2012;119(07):874-879

8 Knight M, Berg C, Brocklehurst P, et al. Amniotic fluid embolism incidence, risk factors and outcomes: a review and recommendations. BMC Pregnancy Childbirth 2012;12:7

9 Stolk KH, Zwart JJ, Schutte J, VAN Roosmalen J. Severe maternal morbidity and mortality from amniotic fluid embolism in the Netherlands. Acta Obstet Gynecol Scand 2012;91(08):991-995

10 Benson MD, Kobayashi H, Silver RK, Oi H, Greenberger PA, Terao T. Immunologic studies in presumed amniotic fluid embolism. Obstet Gynecol 2001;97(04):510-514

11 Benson MD. Current concepts of immunology and diagnosis in amniotic fluid embolism. Clin Dev Immunol 2012;2012:946576

12 Fineschi V, Riezzo I, Cantatore S, Pomara C, Turillazzi E, Neri M. Complement $\mathrm{C} 3 \mathrm{a}$ expression and tryptase degranulation as promising histopathological tests for diagnosing fatal amniotic fluid embolism. Virchows Arch 2009;454(03):283-290

13 Clark SL. Amniotic fluid embolism. Clin Obstet Gynecol 2010; 53(02):322-328

14 Stafford I, Sheffield J. Amniotic fluid embolism. Obstet Gynecol Clin North Am 2007;34(03):545-553, xii

15 Moore J, Baldisseri MR. Amniotic fluid embolism. Crit Care Med 2005;33(10, Suppl)S279-S285

16 Annecke T, Geisenberger T, Kürzl R, Penning R, Heindl B. Algorithm-based coagulation management of catastrophic amniotic fluid embolism. Blood Coagul Fibrinolysis 2010;21(01):95-100

17 Dean LS, Rogers RP III, Harley RA, Hood DD. Case scenario: amniotic fluid embolism. Anesthesiology 2012;116(01):186-192

18 Perozzi KJ, Englert NC. Amniotic fluid embolism: an obstetric emergency. Crit Care Nurse 2004;24(04):54-61

19 Clark SL, Romero R, Dildy GA, et al. Proposed diagnostic criteria for the case definition of amniotic fluid embolism in research studies. Am J Obstet Gynecol 2016;215(04):408-412

20 Peitsidou A, Peitsidis P, Tsekoura V, et al. Amniotic fluid embolism managed with success during labour: report of a severe clinical case and review of literature. Arch Gynecol Obstet 2008;277(03): 271-275

21 Kramer MS, Rouleau J, Baskett TF, Joseph KS; Maternal Health Study Group of the Canadian Perinatal Surveillance System. 
Amniotic-fluid embolism and medical induction of labour: a retrospective, population-based cohort study. Lancet 2006;368 (9545):1444-1448

22 Spiliopoulos M, Puri I, Jain NJ, Kruse L, Mastrogiannis D, Dandolu V. Amniotic fluid embolism-risk factors, maternal and neonatal outcomes. J Matern Fetal Neonatal Med 2009;22(05):439-444

23 Meletti JFA, de Miranda RV. Amniotic fluid embolism during vaginal delivery under analgesia. Case report. Rev Bras Anestesiol 2008;58(04):397-402

24 Clark SL, Belfort MA, Dildy GA, Herbst MA, Meyers JA, Hankins GD. Maternal death in the 21st century: causes, prevention, and relationship to cesarean delivery. Am J Obstet Gynecol 2008; 199(01):36.e1-36.e5, discussion 91-92, e7-e11

25 Rodrigues R, Nunes F, Meirinho M. [Amniotic fluid embolism]. Acta Med Port 2007;20(01):93-95

26 Turillazzi E, Greco P, Neri M, Pomara C, Riezzo I, Fineschi V. Amniotic fluid embolism: still a diagnostic enigma for obstetri- cian and pathologist? Acta Obstet Gynecol Scand 2009;88(07): 839-841

27 Clark SL. Successful pregnancy outcomes after amniotic fluid embolism. Am J Obstet Gynecol 1992;167(02):511-512

28 Duffy BL. Does amniotic fluid embolism recur? Anaesth Intensive Care 1998;26(03):333

29 Collier C. Recurring amniotic fluid embolism. Anaesth Intensive Care 1998;26(05):599-600

30 Stiller RJ, Siddiqui D, Laifer SA, Tiakowski RL, Whetham JC. Successful pregnancy after suspected anaphylactoid syndrome of pregnancy (amniotic fluid embolus). A case report. J Reprod Med 2000;45(12):1007-1009

31 Demianczuk CE, Corbett TF. Successful pregnancy after amniotic fluid embolism: a case report. J Obstet Gynaecol Can 2005;27(07): 699-701

32 Abecassis P, Benhamou D. Is amniotic fluid embolism likely to recur in a subsequent pregnancy? Int J Obstet Anesth 2006;15(01):90 